\title{
Orientalism, Balkanism and Europe's Ottoman heritage
}

\author{
Authors: Dr DerekBryce and Dr SenijaČaušević \\ Annals of Tourism Research \\ Volume 77, July 2019, Pages 92-105
}

\begin{abstract}
'Orientalism' has been used as a lens to understand consumption of heritage sites in nonWestern contexts. Through the supplementary lens of 'Balkanism', we examine a European region with a significant heritage reflecting the c.500 year rule of the Ottoman Empire. Bosnia and Herzegovina, Former Yugoslav Republic of Macedonia and Albania are selected for study given their concentration of Ottoman heritage sites. We note first that these countries' heritage tourism sectors anticipate and modify interpretation to accommodate 'Western' tourists' affectation of 'surprise' and 'delight' at a 'remarkable' crossroads between 'West/East' or 'Christendom/Islam'. To understand why Ottoman heritage is often understood to be in but not of Europe, our analysis draws on scholarship interrogating 'Europe's' longstanding discursive erasure of its Ottoman-Islamic-Oriental 'self'.
\end{abstract}

Keywords: Ottoman; Heritage; Balkanism; Orientalism; Tourist-Subjectivity; European identity

\section{INTRODUCTION}

'History and heritage both refashion the past in present garb ... the former [to] make the past comprehensible, the latter to make it congenial' (Lowenthal, 1998: 148). Heritage tourism is an important manifestation of this. By focusing on one of history's grandest narratives, the binary division between 'East and West', we explore by and for whom and under what discursive conditions this takes place in the presentist terms indicated by Lowenthal and propose that it may be underwritten by a much older set of assumptions. Featherstone (1995) argues that totalising theories of consumer culture produced in the self-constituted 'West' too often obscure the culturally and historically contingent histories from which they themselves emerge. Such elevates the local and particular to the universal because of still-powerful Western-based modes of material and cultural production and naturalised historical narratives (Munslow, 1997; Davies; 2006; Goody; 2006). The binary between East and West, for example, comes to appear inevitable through the co-constructive relationship between popular memory and myth market contestants (Thompson and Tian 2008), authenticating and reproducing received historical narratives.

Our study draws on the long established critical work inspired by Edward W. Said's (1978) Orientalism $^{1}$, which, in the Tourism literature, has, alongside related postcolonial theory, largely been used to account for issues of Western tourism's power over, and cultural commodification of the cultures and histories of destinations deemed subordinate or 'other' (Echtner and Prasad, 2005). This is a well-trodden path and, rather than retrace it, we seek to enrich such work by examining the very roots of the discursive emergence and continued articulation of 'the West' within a particular historical situation in Europe itself, that of the 500 year presence and subsequent heritage legacy of the Ottoman Empire in the Balkans. Contingent histories, and the heritage sites which rely upon or resist them in their tourist

\footnotetext{
${ }^{1}$ We distinguish between Orientalism the book title and Orientalism the discourse with the use of italics.
} 
narrativisation in the Balkans, or SE Europe, provide our contextual focus. We argue for the existence of a longstanding (Western) European disinclination to accept the Ottoman cultural and heritage legacy in places stretching from Budapest to Thessaloniki as being conventionally of Europe or indeed that even less precise construct, 'the West'. The Western discursive manoeuvre, as Bryce (2013) has argued, involves the regular reiteration of pragmatic accommodation at the levels of politics and commerce and subsequent erasure at the levels of culture and heritage of an intrinsic Ottoman-Islamic contribution to European identity. Such an erasure was and is necessary to Europe/the West's subsequent emergence in universalist guise. Drawing on extant theoretical and historical work in the areas of Ottoman and Balkan studies (Sugar, 1977; Todorova, 1994; 1996; 2009; Barkay, 2008; Bryce, 2013), our research questions are: is such a discourse articulated in the production and consumption of heritage tourism in the Balkans and, if so, what are the implications and potential for a more historically complete sense of European identity?

Increasing attention is being focused on how historically informed, ideological (Noy, 2018; Rakić and Chambers, 2012) religious and cultural subjectivities may contest and inform the specifics of tourism consumption. We extend existing work on the reception of Ottoman heritage in the imperial metropole of Turkey (Bryce, 2007; 2011; Bryce and Čaušević, 2016) into an analysis of the experiences of professionals working with the heritage sectors of three of the empire's former European territories: Bosnia \& Herzegovina (Bosnia); Albania and the Former Yugoslav Republic of Macedonia ${ }^{2}$ (Macedonia) to explore supplier experiences of dealing with Western tourist reception of the extensive Ottoman heritage in all three. Notably, Ottoman heritage features very prominently in the tourism promotion efforts in these three countries. We discuss it more thoroughly in the methodology section.

The paper begins with discussion of Orientalism and its reception in the Tourism literature before proceeding with the proposal that it provides an unsatisfactory account on its own for Western understanding of longstanding 'Oriental' presence in Europe itself, requiring the supplementary lens of 'Balkanism' which remains unexplored in the Tourism literature. Attention proceeds to an overview of Ottoman history in Europe and its heritage legacy to add necessary context before moving to an analysis of data gathered from heritage practitioners and tour guides working in Bosnia, Albania and Macedonia.

\section{THEORETICAL AND HISTORICAL BACKGROUND}

\subsection{The Reception of Orientalism in Tourism Studies.}

Some studies take on extended lives as they are taken up by readerships outside the specialist fields from which they emerge. One such title is Said's (1978) Orientalism, which critiqued a hitherto unexamined academic, artistic and political specialisation and shed light on wideranging political and cultural assumptions it supported. 'Orientalism' has been rendered it into a term largely used in critical or cautionary terms today in a range of fields (Spanos,

\footnotetext{
${ }^{2}$ We are cognizant of the ongoing (at time of writing) negotiations between Greece and The Former Yugoslav Republic of Macedonia over the nomenclature of the latter. On September $30^{\text {th }} 2018$, there was a referendum on ratifying Prespa Agreement signed between FYROM and Greece on June $12^{\text {th }} 2018$, on FYROM name change to North Macedonia. However, with only $34.7 \%$ casting a ballot paper, the referendum failed to secure the $50 \%$ turnout required to make the vote valid. Thus, until this is resolved, we trust readers will indulge our use of the term Macedonia rather than the inelegant FYROM in the interests of brevity.
} 
2009) including Tourism where 'cultures of travel' are criticised as privileged patterns of 'engagement and estrangement' (Gregory: 2007: 256) or, as Said (1978) put it, the nonreciprocal power to simply 'be there'.

Said conceived of Orientalism as a mechanism for the self-constitution of that area known as 'the West', first in Europe and subsequently North America and Australasia (Turner, 1994) from roughly the late $18^{\text {th }}$ century Napoleonic invasion of Egypt onwards. Conceiving of Orientalism as a discourse in the Foucauldian sense, Said (1978: 3) states,

\footnotetext{
Orientalism [is the] corporate institution for dealing with the Orient [by] making statements about it, authorizing views of it, describing it, by teaching it, settling it, ruling over it: in short, Orientalism is a Western style for dominating, restructuring, and having authority over the Orient ... [an] enormously productive discipline by which European culture [managed and produced] the Orient politically, sociologically, militarily, ideologically, scientifically and imaginatively during the Post-Enlightenment period.
}

As 'an intellectual event of far reaching implications' (Hussein, 2004: 227), Orientalism's most direct influence was in the field of post-colonial theory, through seminal authors such as Spivak (1999), Bhabha (1994) and Said himself who in subsequent studies like Culture and Imperialism (1993) extended the theoretical implications of Orientalism's specific contextual concerns with the Islamic Near East into the legacies of Euro-American imperialism in the wider world.

Tourism studies drawing on Orientalism might be divided into three broad categories, which descend to the core arguments and contexts of Orientalism in ever decreasing circles of specificity and which tend to use Said's work instrumentally as an analytical lens, rarely critiquing or extending it. These are: works concerned with abstract notions of power and difference (e.g. Tribe, 2006; Baum, 2012; Salazar, 2012); postcolonial studies (e.g. Bruner, 1991; Bhattacharyya, 1997; Bandyopadhyay and Morais, 2005; Echtner and Prasad; 2003; Weischelbaumer, 2012; Losanski, 2013) and the specific context of 'Western' tourism in the Middle East and North Africa (e.g. Gregory, 1999; Burns, 2004; Bryce, 2007; Bryce, MacLaren and O'Gorman, 2013; Scott and Jafari, 2010; Mouffakir, 2015). This study is most closely linked to the third of these but draws closer to 'home', as it were, by examining the conditions necessary for Orientalism's later constitution as a discourse by and for a particular notion of 'Europe'. 


\section{2. 'Balkanism', and the anxieties of Europe.}

What unites both 'Balkan' and 'Oriental' contexts is their former incorporation within the Ottoman Empire, a state straddling Asian, African and European territories. This is a countervailing site of European experience that Western narratives tend to occlude. Therefore, our starting conceptual position is to accept Todorova's (1996: 46) rejoinder to think not of an Ottoman legacy in the Balkans but of the Balkans as the Ottoman legacy and Delanty's (2003: 15) notion of the 'Ottoman-Islamic constellation' as a historically legitimate component of European 'civilisation' insofar as Europe existed within a wider Ottoman orbit. Said (1978: 41,74) was careful to contextualise his critique, stating 'Orientalism carries within it the stamp of a problematic European attitude towards Islam [which was] a real provocation in many ways. It lay uneasily close to Christianity, geographically and culturally'. Said was focused largely on 'the Orient' in its 'external' Middle Eastern and North African manifestations, yet how Europe discursively handled the 'intrusion' of 'the paradox of Turquie d'Europe - in Europe yet of the Orient' (Wolff, 1994: 165) was a question he left largely unexamined.

Our response to this is to align with Bryce's (2013: 118) positing of a necessary 'preOrientalist' discourse within Europe and the 'West' in which 'the anxiety-producing proximity of the Ottoman legacy makes repeated efforts towards its exteriorisation both impossible yet perennially "urgent", in the project of constructing and externalising the 'Orient' proper. The cultural boundaries of 'Europe' are notoriously difficult to define yet discourses of European civilisation that posit fixed cultural frontiers are persistently, and alltoo-often ahistorically, deployed. Jeffrey (2008: 428) makes the telling point that, "with the recent expansion of the EU into Central and Eastern Europe, scholars have conducted sustained deliberation over who, what, or where counts as "European".

Jeffrey (ibid) notes the reinforcing effect the notion of the Balkans as lands of 'ancient ethnic hatreds [and] primordial evil' has for Western-centric notions of European modernity. In doing so, he deploys the critical frame of 'Balkanism' as a supplement to 'Orientalism' in which a liminal 'Balkans as Europe's internal other' is posited as somewhat distinct from the 'external' Orient. If, as Žižek (1996 para. 1/19) claims, 'the object of our perception is constituted through the subject's attitude towards it', the Balkan construct delivers a reification of certain 'European' norms (Todorova 2009). To illustrate, Žižek (2008a; 2008b) argues, from Serbian ultra-nationalist perspectives, the Balkans begin in Kosovo or Bosnia, where a significant proportion of the citizenry is Muslim, positioning Christian Serbia as the protector of core European values (Jeffrey 2008) and the same might be said today of notions of 'Christian Europe's bulwark' propagated in Viktor Orbán's Hungary (Thorleifsson, 2017).

Such endeavours, deriving from the historically recent rise of ethno-nationalism from the $19^{\text {th }}$ century and the quest for cohesive national communities (Anderson, 2006), serve to erase any serious acknowledgment that the much older Ottoman presence in Europe is anything other than an imposition from without, denying its intrinsic place in the development of societies across the Balkans. This can lead, as Allcock (1995) pointed out in Ohrid, Macedonia, to the bringing to light of the Christian character of a heritage site used by multiple faith groups across time and the erasure of its previous Islamic usage. To place our empirical work and analysis in context, it is necessary to first offer a brief account of the expansion of the Ottoman Empire in Southeast Europe and the corresponding syncretic modes of social organisation across faiths which developed as a consequence, resulting in the syncretic 
heritage legacy in the region today. In this we draw largely on Barkay's (2008) comparative sociology of imperial organisation, supplemented by related treatments of Ottoman history.

\subsection{The Ottoman Empire in Europe: expansion and social organisation}

Goffman (2002:6) notes that 'the Ottoman conquest of the Balkans is often imagined as ... the immobilization of a society imprisoned for several centuries in the "yoke" of an exogenous and ungodly conqueror'. Toner (2013) argues that Western Europeans from the Renaissance onwards conceived of the Ottoman Empire as an Islamic, Asiatic 'other', regardless of its duration in Europe and the extensive presence of Europeans in its armies and ruling elite. Western discourse abounds with proclamations of Holy War against the 'Terrible Turk'; warnings by Viennese mothers to their naughty children that they'd 'best behave lest the Turks come and spirit them away' and indeed the notion of Ottoman rule as a barrier to social, economic and cultural development in the Balkans themselves (Kiel, 2002). Such tropes retain traction at popular and political levels and are accounted for in theoretical terms by, for example, Grosrichard (1998) and Cavaliero (2010). As discursive 'positivities' (Foucault 1969:193) such views remain available in the archive of the Western imagination, ready to be redeployed. As such, they cannot be discounted, either in their manifestations in a broad (western) Eurocentrism or in its specific embeddedness in current historiography and national identities in the Balkans (Todorova 1994; 2009).

The Osmanll (Ottoman) dynastic state emerged in northwest Anatolia in the $14^{\text {th }}$ century. Ottoman expansion was, until the early $16^{\text {th }}$ century, largely westward, incorporating, or reducing to tributary status, the territories known today as Greece, Macedonia, Albania, Bulgaria, Serbia, Bosnia, Moldova and Romania (İnalc1k 1994, 2006; Lopasic 1994). The height of Ottoman expansion in Europe (fig. 1) under Sultan Suleiman I (r: 1520-1566), culminated in the conquest of Hungary and first siege of Habsburg Vienna (İnalc1k 1994). Southeast Europe became demarcated by a relatively stable military frontier between Ottoman and Habsburg lands from the end of Suleiman's reign until the first significant Ottoman reverses in the region after 1683 (Goffman, 2002). A correspondingly stable, or at least managed, set of social relations developed amongst Muslims, Christians and Jews which can be identified as specifically Ottoman and which have left a built and intangible heritage legacy common across Southeast Europe.

\section{Figure 1}

The Ottoman state integrated existing and emergent elites from European territories into its civil, military and religious hierarchies and large sections of the population converted to Islam, mainly voluntarily or through the periodic devşirme forced levies (Faroqhi, 2004). Relations of difference and the supremacy of Islam were marked by modes of conduct, deportment and dress (Barkey 2008; Faroqhi and Neumann 2004). Communities were largely self-regulating under the millet system, wherein one was born into a recognised religious community and submitted to its semi-autonomous 'spiritual, financial and administrative authority' (Ortayl1 2004: 18). From the late $15^{\text {th }}$ to late $17^{\text {th }}$ centuries, therefore, the Ottoman state successfully developed a policy of structured toleration towards its non-Muslim population, which operated until the empire's dying days during the Balkan and First World Wars (Faroqhi 2010; Čaušević 2005). 
What emerged was a situation where Islam constituted 'the primary marker of [political] inclusion' and whose legal tenets towards Jews and Christians formed a framework of relations best described as 'separate, unequal and protected' (Barkay, 2008: 120). As Kovač (2006) argues, the non-existence of ethnically based politics for most of the Ottoman period created a heterogenic social texture, constituting a syncretic 'normality' of social experience in stark contrast to Western Europe in the same period. This c.500 year European experience of syncretic social experience under Muslim rule left an indelible heritage legacy, to which we now turn.

\section{METHODS}

Our methodological approach supports the 'discourses of possibilities' implied within 'the natural construction of the social experience' (Kincheloe and McLaren 1998 262). Similar approaches were advocated by Alvesson and Deetz (2000), yet according to Wallace (2005), the former's framework lacks a strong agency to capture the dynamics of experience. Due to the complexity of the settings within the West Balkans, it was difficult to generate relevant knowledge from a single discipline (Doubt 2007). Therefore, our approach is informed by the multidisciplinarity of research sources with data analysis drawing upon existing work related to regional history which is then applied to the contexts at hand (Goulding and Domić 2009, Čaušević and Lynch 2011). We then place the touristic context within the wider frame of the historical and contemporary construction of European identity in relation to the Ottoman past in arts, political, and news-media consumption, bearing in mind Yeğenoğlu's (1998) argument that 'Westerness' refers as much a subjective habitus as it does to a material place.

We undertook an 'in-depth qualitative data capture' (Crouch, 2005; 75) over multiple visits between 2011 and 2014 to the cities of Sarajevo, Mostar, and Počitelj (Bosnia), Tirana and Berat, (Albania), and Skopje and Tetovo, (Macedonia) (Figure 2). Ottoman heritage is present also in other West Balkan states, for instance Greece, Bulgaria, Serbia, etc. however, Ottoman heritage is hardly promoted in tourism purposes, as Philliou (2008, p. 661) argues, the Ottoman legacy is 'what is present, but not perceived'. Ottoman legacy exists, both in tangible and intangible way (Yalouri, 2001), but it is not included in tourism promotion. On the contrary B\&H's, Macedonia's and Albania's tourism narratives purposely weave the narrative of Ottoman heritage as a part of their tourism positioning on the market, rendering it complicit to their own existential identity. The choice of the particular sites is twofold; first, it is a result of the reflection on our previous studies which explored the process of Ottoman heritage commodification, and second, due to their historic significance and deliberate tourism promotion.

Undertaking a sequence of participant observations of guided tours and museum and heritage site visits in all the aforementioned cities we also observed both general city and contextually thematic tours, often more than once. These organisations, practitioners and sites are listed in Table 1 and the participants are anonymised with the exception of S2, who consented to his first name being used to illustrate a particular point. After overt participation observation in tours and site visits, we undertook minimally structured, reflective life-world approaches, using 're-enactment interviews' inspired by Carlsson, Dahlberg, Lutzen and Lystrom (2004) in which participants reflected on their interactions with heritage tourists. We were interested in the particular narrative frames adopted by both tourists and practitioners and the extents to which these aligned or diverged. We conducted theoretical sampling which we performed using snowballing technique (Patton, 1990), which permitted collecting valuable data from the purposefully selected participants, while correspondingly adhering to qualitative nature of 
research (Papadopoulos et.al., 2002). As a measure of research integrity, recruited participants stem from a variety of snowball links. Thus few initial contacts for this research provided contacts within their own networks, which resulted in a rich set of fieldwork data.

Although social science and humanities research thoroughly dealt with the role of ideological and hegemonic discourse in the process of heritage commodification (see for instance Goulding and Domic, 2009; Noy, 2018), tourism studies particularly discuss the role played by heritage site visitors (Chronis, 2012; Rakić and Chambers, 2012) in the process of constructing the commercial heritage narrative. Therefore, our research specifically focused on supply side to explore the experience of local communities in dealing with the issue of heritage commodification through Western tourists' intake of the Ottoman heritage interpretation. Research gives voice to the locals who represent marginalised silent voices, waived into commercial narratives which suite tourist consumption. Local identities are thus constantly in the process of construction through providing the narrative for the tourists.

\section{Figure 2}

Table 1.

In order to analyse the data, we tried to follow Geerts' (1973) advocacy of 'thick description', arguing that theory building may proceed from accounts provided in the language, philosophy, and socio-cultural settings which construct and create public meaning. As Spiggle (1994) notes, this relies upon understanding the point of view of research participants in order to portray broader cultural connotations, with research inquiry focusing on both process and product (Hammersley, 2008). We take the stance that it is the interpellation of tourists in relation to particular historically constructed identities of 'Europeanness' or 'Westerness' that give meaning to experience of the 'Oriental' and syncretic heritage of the Balkans. Therefore, we paid close attention to the history of the Ottoman and subsequent periods in the region as well as related treatments in Cultural Studies and Sociology, giving due place to scholarly work produced in the region and informing our interviews accordingly. If these constituent concepts were observed in isolation, then their meaning would be obscured. We were interested in the particular modes of narrativisation deployed by practitioners and their expectations of reception by tourists. The interviews were conducted in Bosnian/Serbo-Croat (closely related to Macedonian) and English, reflecting the linguistic particularities of each context and the competencies of the authors. Our analysis below is based on illustrative quotes, now presented with regard to the construction, articulation and contestation of binaries through the touristification of Ottoman cultural heritage sites in the West Balkans. The views and perceptions of research participants are integrated into the analysis, with only few indicative statements quoted in the paper to illustrate the main arguments of the interpretation.

\section{ANALYSIS}

Ottoman and subsequent periods in Balkan architectural history are rendered into reductive binary historico-spatial abstractions such as 'Oriental' and 'Modern' (Hadžibegović and Radusić, 2004: 82) which deemphasise the intrinsic role of Ottoman heritage in constructing national identities in the region. Such was reflected in our findings, where the discursive construction of Ottoman era cultural heritage, by both tourists and practitioners, emerges in four related themes: a superimposed 'East/West' binary; the acts of negotiation and resistance 
deployed by practitioners in response; reaction to the 'surprise' effected by tourists at evidence of complex legacies of shared religious and aesthetic experience and, finally, the pragmatic reconciliation of the three preceding. Participants' selected insights are directly integrated into the analysis to illustrate the direction of our arguments.

\section{1. "Talking the language of the tourists'.}

In Baudrillard's (1998 151-152) notion of 'the tragic paradox of consumption', free time first must be purchased prior to cnsumption. One Mostar tour guide (S1), identified time as a limiting factor when explaining the complexities of heritage to tourists, who often expect to have a recognisable interpretive framework reflected back to them rather than investing the 'time' to step out of received narratives. S1 acknowledged that reductive 'East/West' binaries such as 'the place where East meets West'; 'crossroad of civilisations'; 'Sarajevo meeting of cultures' (Figure 3) are easily received by tourists, thus complex historical legacies are often truncated for commercial and operational convenience.

\section{Figure 3}

S1 emphasised that, while tourist interest tended to focus on the legacy of the 1990s' civil war, there was a general sense that Islam in Bosnia is simply the effect of a brutal conquest from the 'East'. Many visitors, she explained, link what they understand as an 'Islamic' conquest with 'terrorism, 9/11 and ISIS'. The principal heritage attraction in Mostar is the famous Ottoman era bridge, destroyed during the 1990s' war and subsequently reconstructed. Using this site as an anchor, S1 expressed a desire to outline a shared local heritage to visitors, telling them that although of Ottoman provenance, it is not a 'Muslim bridge ... it does not belong to Muslims in the city, but to all the citizens of Mostar', presenting the bridge principally through the lens of the 1990s conflict but also framing it in shared historical context.

S1's use of the term 'Turkish' rather than 'Ottoman' raised questions about local as well as visitor understanding of the Bosnian history. She acknowledged that these terms are often used interchangeably in conversations amongst Bosnians, yet they defy attempts to construct a reductive East/West binary when understood in an intrinsically regional context. S2 observed that, '...because many of the tourists I speak to ... when I say Ottoman Empire, they do not know what I am talking about, therefore, in order to simplify the matter, I use the term Turkish', indicating modification and simplification of the actual historical situation to correspond with tourist receptivity.

The unsettled use of this terminology can be seen at some heritage sites (Fig. 4) where the correct use of 'Ottoman' sits next to the more vernacular use of 'Turkish'. This acknowledges the existence of an external perspective where the Ottoman past in the Balkans is more easily received as a simple 'Turkish' occupation. The active participation of non-Turkic subject populations as both rulers and ruled (Barkey, 2008) cannot be reconciled with a will to typify the Ottoman legacy in Europe as that of an exclusively 'Turkish' empire. It appears that presenting it as simply 'Ottoman' does not 'fit' within Western narrativisations of how empires 'work' that depends upon an absolute distinction between 'core' and 'periphery' (Spanos, 2009). 


\section{Figure 4.}

S1 linked this with the more recent erasure of the term 'Bosniak' (Bosnian Muslims) in international discourses on the 1990s' conflict, commenting, 'people always say "the conflict between Croats and Muslims" in Mostar ... very few people say "the conflict between Croats and Bosniaks', linking this with the pejorative use of 'Turk' by Serb nationalists to denote their Muslim neighbours. The discursive effect of this is to deny Bosniaks an autochthonous identity, a consequence of what Bakic-Hayden (1995: 922) identifies as the search for 'original' identities predating the 'common state', both Yugoslav and Ottoman. The pragmatic commercial response was, it seems, to substitute 'Muslim' for 'Bosniak' and 'Turkish' for 'Ottoman'. This contrasted interestingly with our interview at the Sarena Džamija or 'Coloured Mosque' in Tetovo, Macedonia where S19, a member of a political party representing actual ethnic Turkish Macedonians, mentioned his community's desire to integrate but not assimilate with either the majority Slavic/Christian or major minority Albanian-Kosovar/Muslim communities. Clearly, then, binary East/West renderings of Ottoman cultural heritage in the region make little sense when viewed from an intrinsically regional position.

This point was reflected by S2, who observed that a 'binary between the East and the West' is actually created in order to 'talk the language of the tourists'. Yet, S2 also attempted to refine the narrative so that visitors might understand that neither Sarajevo nor Bosnia has been perpetually divided along ethnic, let alone 'East/West' axes. Discussing the reproduction of the East/West dyad through promotion and provision of tourism services, he reflected on his own contrasting position. For him, it was 'normal' to think of Bosnian identity as one culture spanning multiple religious identities, 'something that we take here for granted'; commenting also that at the beginning of his career he was not aware how this might seem quite exceptional to many international visitors. This was mirrored in Tirana by S16 who noted little local bitterness at the fact of Ottoman rule, despite the importance of heroic Albanian national figures like Skanderbeg who resisted it. This, he reflected, may be due to wholesale voluntary conversion of over half the Albanian population to Islam as well as tolerance of Orthodoxy and Catholicism after the Ottoman conquest.

In visiting the city of Berat, a UNESCO World Heritage Site, spared much of the destruction of cultural and religious sites across Albania during the Communist Hoxha regime (19461992), our guide (S17) repeatedly emphasised that, while 'not very religious these days' the inhabitants of the city were of both Orthodox-Christian and Muslim backgrounds and, this is not 'simply co-existence, but complete understanding and appreciation of each other' pointing to the excellent state of preservation of Orthodox churches that had preceded the Ottoman conquest and had been maintained during and after it. These encounters led us to focus on the discourses used by heritage practitioners to ameliorate many tourist assumptions.

\section{2. 'An ethical obligation to my country'.}

'So, you are interested to know more about the war?' asked Sarajevo guide (S3). Surprised at our interest on his views of tourist reception of Ottoman heritage, he commented that, to many visitors, the country seemed not to have existed prior to the 1990 s conflict. S3 identified an initial, commercially driven, need to simplify wider legacies because of tourist interest in 'the last war', and that familiarity with 'sensationalist journalism' both shapes perception and provokes curiosity. Nonetheless, S3, to whom we will shortly return, felt an 
'ethical obligation to my country' to guide visitors to more historically nuanced interpretations of it. The notion of the intrinsic place of Islam in a European context is the problematic component underwriting the very need to construct the Balkans in binary terms, both internally and externally. The inevitability of such externalising, indeed dehistoricising, discursive manoeuvres is cast into doubt when, for example, Bosniaks or Albanians themselves, whether practicing Muslims or those with ancestral links to the faith, were asked to reflect on the issue.

First, it must be emphasised that Islamic religious architecture in the Balkans is both 'Ottoman', in vernacular terms and 'local' in patronage terms. As Kuban (2010: 571) explains, there was an emphasis on symbolically assimilating 'new Islamic territory' through its embellishment with religious architecture evoking that of the imperial capitals of Bursa, Edirne and Istanbul. In this sense, the Balkans is amongst the most visibly 'Ottoman' areas of the former empire. From the $16^{\text {th }}$ century consolidation of Ottoman rule, however, 'this building activity was largely in the hands of great regional Slav [and Albanian] families who had accepted Islam and come to form the Ottoman devşirme bureaucracy. This Slavicspeaking Muslim community created the culture that came to represent the Ottoman Empire in Europe' (ibid: 587). This potent expression of imperial metropolitan taste shows that to be Ottoman was to be simultaneously imperial and local and is present in often extravagant visual terms throughout the region in its built heritage. Visiting an example of this, the $16^{\text {th }}$ century Begova Dzamija (Bey's Mosque) in Sarajevo, allowed this dimension of culturalreligious nuance to emerge in sharp relief. A custodian and Islamic scholar (S11) began by commenting on tourists' naive understanding of Islam and a general conflation of the faith with its more radical adherents.

This allowed us to reflect on S2's previous observation that, "when I say to American tourists that my name is Muhamed, they think that I am joking. They expect an Arab with a long beard. This is Muslim for them ... they end the tour and they are completely puzzled by my look'. At this stage S3 intervened to insist that S11 comment on the presence of 'Salafis and Wahhabis' in Bosnia, declaring to us that 'I know that you will not ask this question, but I want to ask it!' S11 responded that he thought that while the issue was exaggerated in international and domestic media, 'basically Wahhabis' idea of Islam is to return it to the way as it was 1000 years ago ... they think that Islam in Bosnia is corrupted and changed over the centuries'. S11 focused on what he perceived to be themes of tolerance in Islam, particularly in the multireligious Ottoman context, commenting that, 'many tourists change their view on Islam after visiting Bosnia'. Emphasising the importance of distinguishing between regional Islamic heritage in its historical specificity, and contrasting with the generic modernity of recent Saudi funded facilities, S3 commented that, 'Ottoman mosques are small ... built beautifully ... so romantic, and they fit so well in the city's landscape', thereby laying claim to that faith's intrinsic place in local and regional heritage.

Similar tensions in the interpretation of Islamic heritage in the region were apparent when interviewing at the Arabati Baba Tekke, a lodge of the Bektashi Sufi order, in Tetovo, Macedonia. S20, a member and representative of the mainstream Sunni community which now has control over most of the site, acted as a gatekeeper, offering an 'orthodox' narrative to visitors in which the founding Bektashi dervishes were described as 'in error' and 'heretical' in their beliefs. This contrasted with the interpretation provided by one of the few remaining dervishes still present at the site (S21). He related how the Bektashi, a mystical, syncretic order, preceded the Ottoman armies in the Balkans, heralding the new Islamic faith, but acknowledging and absorbing elements of existing Christian and folk beliefs. Similarly, 
S16 was at pains to point out that Islam in Albania is very liberal in its articulation and not associated as an exclusive marker of imperial rule. So there was a strong sense in all three countries of Ottoman and Islamic heritage as constituent components of national and regional identities in Europe.

These challenging encounters served to raise two important, related issues on the question of religion and the symbolic potency of heritage in the region. First, that a type of 'East/West' binary within heritage practitioners' sense of 'legitimate' Islam, bound up with externally driven discourses on 'radical Islam' and the 'War on Terror' may be at play. Second, that the local provenance of long-established Islamic practice, an extensive built environment that reflects this, with its roots within an Ottoman social framework that accommodated and normalised 'difference' could be deployed as both 'refuge' for local people themselves and as counterpoint to be presented to those international tourists holding undifferentiated narrative accounts of Islam's place in Europe.

\section{3. 'We were here before East and West was invented!'}

This notion of the historical fragility of what may seem to be a timeless binary notion of the meeting of civilisations has particular resonance when attention turns to the legacy of Muslim, Christian and Jewish coexistence during the Ottoman period. S3 observed that, 'we take it for granted, and we think that we are special because we built the bridge between the East and the West ... but that was always there, East and West were always here, and we do not think about that ... we were here before East and West was invented!'. With this profound statement in mind, we returned to Old Sarajevo with S3 on a tour of the Annexes of the Sarajevo Museums: Despica House (Orthodox Christian House), Svrzo's House (Muslim House) and the Jewish Museum and Synagogue.

The first and second floors of Despica House present life during the long Ottoman (1463 1878) and brief Austro-Hungarian (1878-1918) periods of rule. A site custodian, S4, recalled many visitors' surprise that the first floor of the house is designed in an 'eastern' style, which they seemed to associate exclusively with 'Turks' and Islam. Saying that it 'seems that the tourists bring lots of prejudices with them', S4 speculated that it may be difficult for tourists to reconcile the house's ownership by a wealthy Christian family given its design in an Ottoman vernacular. A colleague, S5, recalled being asked by visitors if they had reached 'the right place', and 'is this a Muslim house? It is all done in a Turkish way!' S4 interjected, 'we explain that we wanted to present it as it was. This was fashionable at that time, and comfortable too. So, wealthy people would be able to afford it'. This corresponds with Sugar's (1977: 225) explanation that, in the Ottoman period, 'because the Muslims had both old and new rich among them, this group automatically enjoyed the highest prestige and gave the tone to "high society" [so the] the richer a non-Muslim became, the more his home and clothing resembled those of the Muslims'.

This seems an unproblematic truism when reflecting on the diffusion of elite taste as a general phenomenon of consumption (e.g. Meier 2000), yet, when presented as a facet of regional heritage, it is filtered though binary expectations brought by those tourists who find the notion of non-Muslim inclusion in secular Ottoman aesthetics 'remarkable' and 'extraordinary'. On a tour of Sarajevo's Old Orthodox Church and its Franciscan Monastery, S15, whose interfaith tours emphasise the syncretic nature of Bosnian heritage, emphasised how both Christian and Muslim practise was subtly shaped during Ottoman times because of community overlap. She commented, 'this is, or was, quite normal for us in a day to day 
sense but seems surprising to outsiders ... we try to explain this normality to them'. Meanwhile, S17 at Berat Citadel, Albania, stated that intermarriage was and is common and Islam was practiced alongside Orthodox Christianity peacefully during the Ottoman period. This heritage of tolerance was brought into stark relief when considering the social position of Jews in the Ottoman Empire.

Sarajevo's Jewish Museum and Synagogue represents, on its lower floors, community life during the Ottoman, Austro-Hungarian and Yugoslav periods until 1941 when the massmurders of the Holocaust greatly reduced the once thriving community. Judaism has been present in Europe since Antiquity but the later arrival of a specific and significant component of the Jewish population was as a result of deliberate Ottoman policy to offer refuge in the empire to Sephardim after their persecution and expulsion from Catholic Spain from the mid 1500s (Goffman, 2002). The museum's custodian (S6), a member of Sarajevo's small remaining Jewish community, noted that visitor response to the site seemed to be filtered through recent assumptions of irreconcilability between Judaism and Islam. A frequent theme in tourists' questions about life during the Ottoman period was 'whether it was difficult for Jews to live with Muslims'. S6 considered this to be a result of exposure to media coverage of conflict in Israel/Palestine, embedding narratives of 'timeless' antipathy.

Consequently, S6 perceived a responsibility to highlight that, 'this museum shows the life of the Jewish community in Sarajevo and also how well integrated the community was'. This comment was underpinned by the recognition that new Jewish arrivals to Sarajevo, and the empire generally, brought skills that the Ottoman authorities perceived to be economically beneficial (Faroqhi, 2010). This Ottoman attitude was instrumental, but nonetheless drew upon long extant models of Jewish-Christian-Muslim coexistence around the eastern and southern Mediterranean, Iberia and Middle East. This constitutes a 'normality of altereity' that, as Chambers (2008: 130-133) argues, can be difficult for normative, 'Western' notions of modernity to receive.

At Svrzo's House, the former home of a wealthy Muslim family, the custodian (S7) observed that many tourists come with certain exaggerated preconceptions regarding Muslim family life, focusing on gender relations and polygamy. For instance, S7 recalled how 'a group from Slovenia asked me whether I have four wives. Imagine that! Thirty years ago we lived in the same country, have they forgotten that?' For S7, the problem did not solely lie in unfamiliarity with the contemporary reality of Muslim family life in Bosnia, but with how the recent shared history of Yugoslav experience could be subsumed under narratives of the 'alien' position of Islam in Europe. The commercial utility of such binary discourses as a means to address a 'Western' subjectivity that wishes to consume 'oriental otherness' in relation to itself, has long been present in tourism promotion of Turkey and specifically the former Ottoman capital, Istanbul (Bryce, 2011). The mobility of this binary, moving easily from Istanbul to Sarajevo, reinforces Bryce's (ibid) argument that a certain 'anxiety as enjoyment' is at play in the interpellation of tourists as 'Western' subjects. That is to say, the material Ottoman legacy in European space is rendered into a perhaps less unsettling spatial abstraction (Bryce, 2013).

If the border and crossroads between East and West are spatially and historically mobile, depending on the situation to which the binary is applied, then it appears that a specific 'symbolic geography' (Žižek 2008a; Todorova, 2009) underpins evocations of the Balkans, where the nodal point of the binary shifts depending on interpretation and point of view. In heritage-tourism rendering of both Sarajevo and Istanbul, for example, the point 
differentiating 'East' from 'West' is Islam. However, the story of Islam in Europe generally, and the Ottoman case specifically, is more nuanced. The binary representation is both a response to external spatial framing of cultural complexity and, to a certain extent, an expression of ethno-nationalist superimpositions within the post-Ottoman Balkans. Yet, this latter invocation of the binary is supplementary to an older awareness of a shared Ottoman past.

\section{4. '... but at least we can here try to present it in a way that we are a part of Europe':}

From a destination positioning perspective, the binary is commercially useful and destination marketers and tour guides deploy it for instrumental reasons with some success. Over the last decade, after all, overseas tourist arrivals in all three national contexts here have shown year on year increases with Bosnia attracting c.1.1 million, Macedonia c.8.5 hundred thousand and Albania c. 4 million visitors in 2016 (Bosnia and Herzegovina Agency for Statistics, 2018; Republic Macedonia, State Institute for Statistics, 2018; Albania Tourism Statistics, 2018). However, this obscures a core historical element of identities in the Balkans; the routine negotiation of overlapping religious and cultural practises. As Europeans, practitioners are members of their given societies after all, and find this component 'normal', yet do not always prioritise it in relation to the binary assumptions brought by many visitors. Therefore, as transmitters of semiotic codes, they actually need to translate for Western tourist subjectivity, only thereafter carefully introducing those characteristics of regional history that might act as a corrective. Tourists like what they hear; it is quite exciting for them to be in the place where 'East and West meet'.

When invited to reflect on this point, S2 commented that '...people come here with a lot of prejudices, so you have to explain something what we find here normal'. Proceeding to acknowledge the power of promotional material in this respect, he continued:

\footnotetext{
... that Bosnian promotion ... 'come to Bosnia, a country where east meets west', it does help a lot, although it is a stereotype, you cannot present it differently, Sarajevo is not a modern metropolis, it is not oriental either, so although this helps, it can be misleading ... but at least we can here try to present it in a way that we are a part of Europe.
}

What S8, an international development worker in the heritage field, seemed to evoke is a growing awareness of the importance of emphasising heritage diversity in the case of Bosnia, which, we argue, is a potent manifestation of the legacy of Ottoman social organisation across the region:

I mean, we promote what we can sell, but of course we take care that all sides are there. Tourists already know about Mostar Old Bridge. Then there is Sarajevo Cathedral, Bey’s Mosque, Jewish Haggadah, Orthodox Monasteries... all interesting tourism aspects.

S18, an official city tour guide in Skopje, reflected a sense of the Ottoman period as being, in places, a source of shared history and achievement. His attitude when taking us across the Ottoman era 'Stone Bridge' into the 'Čaršija', or old Ottoman city, was ambivalent. He presented Ottoman rule as one barrier to realisation of Macedonian nationhood yet expressed pride that the classically Ottoman designed Stone Bridge was the product of 'a shared endeavour by all the people' and placing the various religious sites in the 'Čaršija', including the Orthodox Church of Holy Salvation, the $15^{\text {th }}$ century Ishak Bey Mosque (fig. 5) and the 
various secular buildings from the period in relational not oppositional terms, reflecting, in this instance, close congruence with the historical record (Ćurčić 2010: 758).

\section{Figure 5.}

We could see that these monuments are presented in association and seem to attain some sort of heightened symbolic effect as a result. So, while acknowledging that heritage syncretism is a distinguishing 'asset' for all three countries we, yet, return to the point that a binary discourse is, subsequently, superimposed as a way to 'make sense' of it for international visitors.

\section{CONCLUSION.}

In order to ease the reception of unfamiliar historical representations, complex, overlapping socio-historical experiences are often transformed into easily consumable 'banal' narratives, better suited to benign leisure experience (La Capra 2001). This is not simply a matter of facilitating 'easy' consumption through simplification of historical complexity but also the interpellation of particular visitor groups as historically constituted tourist subjects in relation to a destination's cultural heritage. Here, we focused on a particularly potent manifestation of this in the production and reception of Southeast Europe's Ottoman heritage, arguing that it constitutes a surface of emergence of a centuries old discourse of accommodation/exclusion of what is within but not of Europe. This necessarily precedes and creates the condition of possibility for subsequent binary, power-laden divisions of the wider world into imaginary geographies of core and periphery like West/East, Occident/Orient, Christendom/Islam and Modernity/Tradition.

Containing a significant Muslim community or heritage legacy in Europe, much of the Balkans does not 'make sense' - is 'remarkable' - and must, therefore, be constructed as a de-historicised anomaly in order to accommodate Western-identified subjectivity. The 'remarkable' richness of Ottoman heritage is in its intertwined Islamic, Christian, Jewish and European makeup. Philliou (2008) argues that the Ottoman legacy is what is present, but not perceived, in most of the former Ottoman territories, being subsumed under exclusionary ethno-nationalisms internally and by binary constructs that simplify its position in civilisational terms externally. The latter dimension may be refined into two further binaries: between East and West (Islam and Europe), denoting an 'external' other, and between Europe and an internal European 'Balkan' other. The latter component denotes the anxiety provoked by the 'intrusion' of the 'East' and 'Islam' into interdictory European space.

This simplification of syncretic complexity in order to conform to favoured narrative tropes wreaks symbolic violence on not only the identity of the Balkan countries and Turkey, but on the notion of what it truly means to be European in the widest historical sense. Guattari (1989) argues the process of experience creation is often underwritten by slogans invoking certain states of mind, for instance 'Bosnia and Herzegovina - the crossroads of civilisations', or 'Istanbul: the city where East and West meet', reinforcing and normalising supposed binary distinctions between East (Islam) and West (Christendom). Left unattended, such narratives become the medium for particular messages to take charge of, reorganise and 'make sense' of heritage in particular ways for particular audiences (White, 1987). As we have noted above, many heritage practitioners in Southeast Europe are put into the position of having to resist, ameliorate or become complicit in this restructuring of their own history and heritage. 
The designation of Ottoman heritage as religiously and civilisationally remote from Europe produces a de-historicised identity for both the Balkans and the subject positions of 'Western' tourists. The post-Ottoman Balkans does not readily correspond to certain internalised notions of that which is conventionally of Europe; it needs to be constructed as 'exceptional', where that which is perennially external meets Europe. The discursive relationship at hand is therefore more proximate, indeed intimate, than that between 'Europe' and the Arab-Islamic 'other' at stake in Said's critique of Orientalism or indeed the wider field of postcolonial critique that emerged from it. Rather, it is the anxiety inducing, and therefore occluded, proximity of the Ottoman-Islamic European self that is at stake (Bryce, 2013).

Clearly contemporary questions of national identity cannot be superimposed seamlessly upon that Ottoman framework. Nor are the notions that 'timeless' hatred was unleashed in the early 1990s as the Yugoslav state unravelled easily dislodged (Simms, 2001; Čaušević and Lynch, 2011). Yet it may be that the shared Ottoman legacy may constitute a historically secure basis for shared memory and identity, principally for the aim of post-conflict reconciliation but also in articulating the region's cultural heritage to international tourists. This need not simply be couched in terms of facilitating banal 'amazement' at the presence of churches, synagogues and mosques in close proximity in Balkan cities, but in terms of presenting tourists with a nameable, concrete historical situation and legacy; a shared, longstanding socio-cultural experience mandated by the Ottoman Empire as a European state. Talk of Balkan 'liminality' and 'meandering' between Occident and Orient, East and West, signify nothing more than a European disinclination to either integrate its Ottoman-Islamic self or be integrated with the 'Orient' that it so diligently exteriorises.

Therefore, we found not so much a narrative representing regional cultural heritage but a iteration of an unresolved European anxiety about its own Ottoman past. White (1987) tells us that, although requiring translation, the narrative form in which 'stories' are told by one culture to another is comprehensible in the sense of the form, if not necessarily the content, being that rarest of artefacts, a 'meta-code' shared across cultural frontiers. Our participants are undertaking the task of resisting and ameliorating Western tourist narratives in ad-hoc terms by introducing a counter-narrative of syncretism to make sense of the overlapping diversity of religious and social heritage in Southeast Europe made possible by the Ottoman system of rule. If formalised, this may yet form part of the wider project of both 'provincialising' Europe (Chakrabarty, 2000) and the wider West and reintegrating them in a more complete narrative understanding of the world's rich and interlocking relationships of both history and heritage. 


\section{REFERENCES}

Agency for Statistics, Bosnia and Herzegovina (2018). Tourism Statisitics. Accessed: 29 September 2018. <http://www.bhas.ba/saopstenja/2018/TUR_02_2017_12_0_EN.pdf $>$

Allcock, J.B. (1995) International tourism and the appropriation of history in the Balkans. In: M.F. Lanfant; J.B. Allcock and E.M. Bruner (Eds) International Tourism: identity and change. London: Sage.

Alvesson, M; Deetz, S (2000) Doing Critical Management Research. London: Sage.

Anderson, B. (2006) Imagined Communities: reflections on the origin and spread of nationalism. London: Verso.

Bakić-Hayden M, 1995, "Nesting Orientalisms: The Case of Former Yugoslavia" Slavic Review 54(4) 917-931.

Baum, T (2012) Working the skies: Changing representations of gendered work in the airline industry, 1930 -2011. Tourism Management. 33 1185-1194

Bandyopadhyay, R; Morais, D (2005) Representative Dissonance: India's self and Western image. Annals of Tourism Research. 32(4) 1006-1021

Barkey K. (2008) Empire of Difference: the Ottomans in comparative perspective. Cambridge: Cambridge University Press.

Baudrillard J. (1998) The Consumer Society: Myths and Structures. London: Sage.

Bhabha, H.K., 1994. The Location of Culture. London: Routledge.

Bhattacharyya, D., (1997) Mediating India: an analysis of a guidebook. Annals of Tourism Research. 24(2) 371-389.

Bruner, E.M., (1991) Transformation of Self in Tourism. Annals of Tourism Research. 18(?) 238-250.

Bryce, D. (2013) The Absence of Ottoman, Islamic Europe in Edward W.Said's 'Orientalism'. Theory, Culture and Society 30(1) 99-121.

Bryce D. (2011) Turkey, Tourism and Interpellated 'Westernness': Inscribing Collective Visitor Subjectivity. Tourism Geographies 14(3) 444-466.

Bryce, D. (2007). Repackaging orientalism: discourses on Egypt and Turkey in British outbound tourism. Tourist Studies, 7(2), 165-191. 
Bryce, D., \& Čaušević, S. (2016). Domesticating fears and fantasies of 'the East': integrating the Ottoman legacy within European heritage . Journal of Marketing Management, 32(1516), 1419-1440.

Bryce, D., Maclaren, A., \& O'Gorman, K. D. (2013). Historicising consumption: Orientalist expectations of the Middle East. Consumption, Markets and Culture, 16(1), 45-64.

Burns, P.M., 2004. Six Postcards from Arabia: a visual discourse of colonial travels in the Orient. Tourist Studies, 4(3), pp. 255-275.

Carlsson, G., Dahlberg, K., Ekebergh, M., and Dahlberg, H. (2004). Patients longing for authentic personal care: A phenomenological study of violent encounters in psychiatric settings. Issues in Mental Health Nursing, 25, 191-217.

Čaušević Dž. (2005) Pravno - politicki razvitak Bosne i Hercegovine : dokumenti sa komentarima Sarajevo: Magistrat.

Čaušević S. and Lynch P. (2011) Phoenix Tourism: Post-Conflict Tourism Role. Annals of Tourism Research 38(3) 780-800.

Cavaliero, R., (2010) Ottomania: the Romantics and the myth of the Islamic Orient. London: I.B. Tauris.

CEIC (2018) Albania Tourism Statistics. Accessed: 29 September 2018. $<$,https://www.ceicdata.com/en/albania/tourism-statistics $>$

Chakrabary D, 2000, Provincialising Europe. Princeton NJ: Princeton University Press

Chambers I, 2008 Mediterranean Crossings: the politics of an interrupted modernity Durham, NC: Duke University Press.

Crouch D, 2005, "Tourism Research Practices and Tourist Geographies" in Tourism Research Methods: Integrating Theory with Practice Eds B Ritchie, P Burns, C Palmer (CABI, Wallingford) pp. 73-85.

Ćurčić S, 2010, Architecture in the Balkans: from Diocletian to Süleyman the Magnificent New Haven, CT: Yale University Press.

Davies M, 2006, Historics: why history dominates contemporary society. Abingdon: Routledge.

Delanty G, 2003, The making of a postwestern Europe: A civilizational anlaysis. Thesis Eleven 72(1). 8-25 
Echtner, C; Prasad, P. (2003) The context of Third world tourism marketing. Annals of Tourism Research. 30(3). 660-682.

Faroqhi, S (2010) Subjects of the Sultan: culture and daily life in the Ottoman Empire. London: I.B. Tauris.

Faroqhi S, 2004 The Ottoman Empire and the World around it. London: I.B. Tauris.

Faroqhi S, Neumann C, 2004 Ottoman Costumes: from textile to identity. Istanbul: Eren.

Featherstone, M (1995) Undoing Culture: globalisation, postmodernism and identity. London; Sage.

Foucault, M (1969) The Archaeology of Knowledge. London: Routledge.

Geertz, Clifford (1973). The Interpretation of Cultures. New York. Basic Book

Goffman D, 2002 The Ottoman Empire and Early Modern Europe. Cambridge: Cambridge University Press.

Goody, J (2006) The Theft of History. Cambridge: Cambridge University Press.

Gregory, D (2007) The Colonial Present. Oxford: Blackwell.

Grosrichard, A (1998) The Sultan's Court: European fantasies of the East. London: Verso.

Guattari, F, (1989). The Three Ecologies. London: Continuum.

Hammersley, M (2008). Questioning Qualitative Inquiry. London: SAGE

Hadžibegović I, Radušić E, 2004, "From an Oriental Islamic City to a European City" in Svejetlost Evrope u Bosni i Hercegovini Eds I Huseinović, D Babić. Sarajevo: BuyBook.

İnalc1k H, 1994, The Ottoman Empire: the classical age 1300-1600. London: Phoenix.

İnalcık H. (2006) Turkey and Europe in History. Istanbul:Eren. 
Jeffrey A, 2008, Contesting Europe: the politics of Bosnian integration into European structures. Environment and Planning D: Society and Space 26(3) 428-443.

Kiel, M., (2002) Looking Backward - Looking Forward: seventy five years of study of the history and culture of Islam in South-eastern Europe. In: Proceedings of the International Symposium on Islamic Civilisation in the Balkans. Istanbul: Research Centre for Islamic History, Art and Culture.

Kincheloe, J. L., and McLaren, P. L. (1998). Rethinking critical theory and qualitative research. In N. K. Denzin and Y. S. Lincoln (Eds.), The landscape of qualitative research (pp. 260-300). Thousand Oaks: Sage.

Kovač N, 2006, Political Reflections. in Unity and Plurality in Europe. Ed R Mahmutčehajić. Sarajevo: International Forum. pp. 87-101

Kuban D, 2010 Osmanlı Mimarisi. Istanbul: Yapı Endüstri Merkezi Yayınları.

LaCapra D, 2001 Writing history, writing trauma. Baltimore: John Hopkins University Press.

Lopasic A, 1994, Islamization of the Balkans with Special Reference to Bosnia. Journal of Islamic Studies 5(2) 163-186

Losanski, K., (2013) Encountering Beggars: disorienting travellers? Annals of Tourism Research. 42. 46-64.

Lowenthal, D., (1998) The Heritage Crusade and the Spoils of History. Cambridge: Cambridge University Press.

Meier H-D, 2000, Taste Formation in Pluralistic Societies: the role of rhetorics and institutions. International Sociology 15(1) 33-56

Mouffakir, O., (2015) The Stigmatized Tourist. Annals of Tourism Research. 53(?) 17-30.

Munslow A, 2006 Deconstructing History. London: Routledge.

Noy, C. (2018). Memory, Media, and Museum Audience's Discourse of Remembering. Critical Discourse Studies, 15(1), 19-38.

Philliou, C. (2008). The Paradox of Perceptions: Interpreting the Ottoman Past through the National Present. Middle Eastern Studies, 44(5), 661-675. 
Rakić, T. and Chambers, D. (2012) Rethinking the consumption of places. Annals of Tourism Research, 39 (3). pp. 1612-1633.

Republic of Macedonia, State Institute for Statistics (2018). Tourist Arrivals. Accessed: 29 September 2018. <http://makstat.stat.gov.mk/PXWeb/pxweb/mk/MakStat/?rxid=d8a47462a6ab-4901-8936-7bee6bdcc8de>

Said E.W. (1978) Orientalism. London: Penguin.

Said, E.W. (1993) Culture and Imperialism. London: Vintage.

Salazar, N.B., (2012) Tourism Imaginaries: a conceptual approach.Annals of Tourism Research. 39(2) 863-882.

Scott, N; Jafari, J (2010) Tourism in the Muslim World. Bingley: Emerald.

Simms B, 2001 Britain and the destruction of Bosnia. London: Penguin.

Spanos W, 2009 The Legacy of Edward W. Said. Chicago: University of Illinois Press.

Spiggle, S. (1994). Analysis and Interpretation of Qualitative Data in Consumer Research. Journal of Consumer Research. 21, 491-503.

Spivak, G (1999) A Critique of Postcolonial Reason: Toward a History of the Vanishing Present. Cambridge, MA: Harvard University Press.

Sugar P, 1977 Southeastern Europe under Ottoman rule, 1354-1804. Seattle: University of Washington Press.

Thompson, C; Tian, K. (2008) Reconstructing the South: How Commercial Myths Compete for Identity Value through the Ideological Shaping of Popular Memories and Countermemories. Journal of consumer Research. 34(5) 595-613.

Thorleifsson, C., (2017) Disposable strangers: far-right securitisation of forced migration in Hungary. Social Anthropology. 25(3) 318-334

Toner J, 2013, Homer's Turk: how classics shaped ideas of the east. Cambridge, MA: Harvard University Press.

Todorova M. (1994). The Balkans: From Discovery to Invention. Slavic Review 53(2) 53482.

Todorova M. (1996) The Ottoman legacy in the Balkans. In Imperial legacy: The Ottoman imprint on the Balkans and the Middle East Ed L. C. Brown. New York: Columbia University Press. pp. 45-77. 
Todorova M. (2009) Imagining the Balkans. Oxford: Oxford University Press.

Tribe, J., (2006) The Truth about Tourism. Annals of Tourism Research. 33(2) 360-381.

Turner, B.S. (1994) Orientalism, Postmodernism and Globalism. London: Routledge.

Wallace, B. (2005) 'Exploring the meaning(s) of sustainability for community-based social entrepreneurs', Social Enterprise Journal 1 (1) pp. 78-89.

Weischelbaumer, D. (2012) Sex, romance and the carnivalesque between female tourists and Caribbean men. Tourism Management. 33(?) 1220-1229.

White, H., (1987) The Content of the Form: narrative discourse and historical representation. Baltimore: Johns Hopkins University Press.

Wolff, L., (1994) Inventing Eastern Europe: the map of civilisation on the mind of the Enlightenment. Stanford NJ: Stanford University Press.

Yeğenoğlu Meyda, 1998 Colonial Fantasies: towards a feminist reading of Orientalism (Cambridge University Press, Cambridge)

Žižek S, 1996, "Underground, or Ethnic Cleansing as a Continuation of Poetry by Other Means", InterCommunication, No. 18, Autumn 1996, 19 paragraphs, http://www.ntticc.or.jp/pub/ic_mag/ic018/intercity/zizek_E.html

Žižek S, 2008a, The Military-Poetic Complex. London Review of Books [Online] vol. 30 no. 16 p. 17. Available fromhttp://www.lrb.co.uk/v30/n16/slavoj-zizek/the-military-poeticcomplex [Accessed 25 February 2012].

Žižek S, 2008b Violence London: Verso. 